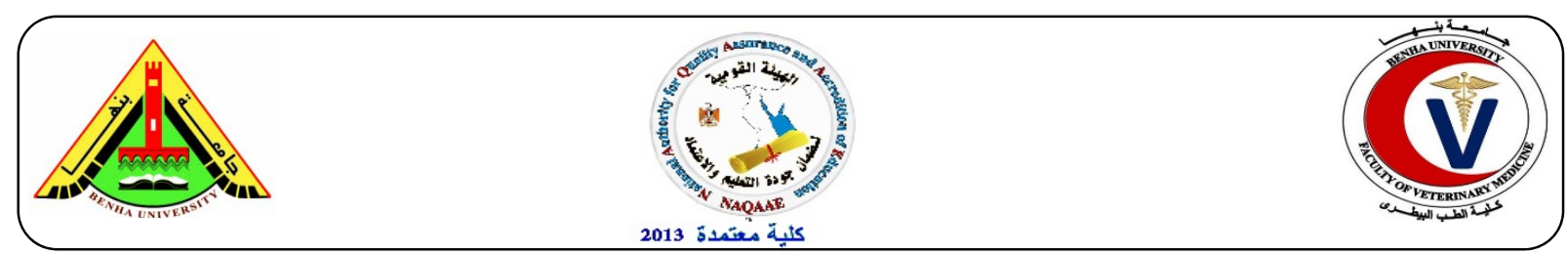

\title{
Demonstration of Cadmium and Lead residues in Imported Frozen Fish
}

\author{
Hassan, M.A. ${ }^{1}$, El- Shater, M.A. ${ }^{2}$ and Waly, H.A. ${ }^{3}$ \\ ${ }^{1}$ Food Hygiene Control Department, Faculty of Veterinary Medicine, Benha University. ${ }^{2}$ Animal Health Research \\ Institute, El-Doki. ${ }^{3}$ General Authority for Veterinary Services, Menoufiya, Berket El-Sabaa
}

\begin{abstract}
A B S T R A C T
A total of ninty random samples of imported frozen fish represented by Mackerel, Herring and Saurus (30 of each) imported from two different countries namely A and B (15 samples of each fish species for each country) were collected from different fish markets in Menoufiya governorate. The obtained results recorded that the occurrence of cadmium in country (A) were 53.33, 40.00 and 33.33\% in the Mackerel, Herring and Saurus samples, respectively. In country (B) the cadmium occurrence was 40, 26.67 and $20.00 \%$ in the Mackerel, Herring and Saurus samples, respectively. In addition, our results recorded that the percentage of occurrence of lead in country (A) were $66.67,66.67$ and $53.33 \%$ in the Mackerel, Herring and Saurus samples, respectively; while in country (B) were 60, 46.67 and $40 \%$ in the Mackerel, Herring and Saurus samples, respectively. It could be inferred that regarding the products contamination, the highest cadmium and lead contamination was in mackerel followed by herring then saurus. Regarding the locality, country (A) represented the highest contamination of both cadmium and lead followed by country (B).
\end{abstract}

Keywords: Mackerel, Herring, Saurus, cadmium and lead

(http://www.bvmj.bu.edu.eg)

(BVMJ-32(1): 79 -82, 2017)

\section{INTRODUCTION}

The problem of chemical residues in food has been addressed at international level through deferent committees sponsored by some United Nations Organizations (FAO/WHO, 1992). The pollution of imported frozen fish with heavy metals constitutes a public health hazard during recent years. Cadmium is classified as a probable human carcinogen. Chronic exposure to cadmium is also associated with a wide range of other diseases, including heart disease, anemia, skeletal weakness, depressed immune system response as well as kidney and liver disease (Codex Alimentarius Commission Procedural Manual, 2001). Lead is considered as a toxic substance, which accumulates in body due to low rate of elimination (Underwood, 1977). Moreover, lead levels in imported frozen fish over permissible limits are implicated in chronic lead toxicity results in abdominal pain, anemia, encephalopathy and renal damage. Recently, lead is considered as one of immunosuppressive agents in both animal and human (Andreji et al., 2005).

The aim of the present work was to determine cadmium and lead (heavy metals) in imported frozen fish which could be indicative to its healthiness for human consumption.

\section{MATERIAL AND METHODS}

\subsection{Collection of samples:}

A total of 90 random samples of imported frozen fish represented by Mackerel, Herring and Saurus (30 of each) imported from two different countries namely A and B (15 samples of each fish species for each country) were collected from different fish markets in Menoufiya governorate. The collected samples were examined for determination of cadmium, lead levels on the basis of wet weight $(\mathrm{mg} / \mathrm{Kg})$.

\subsection{Determination of heavy metals:}

\subsubsection{Digestion technique:}

Accurately, $2 \mathrm{~g}$ of each sample were macerated by sharp scalpel and digested by $10 \mathrm{ml}$ of digestion mixture $(60 \mathrm{ml}$ of $65 \%$ Nitric acid and $40 \mathrm{ml}$ of $70 \%$ perchloric acid) in screw capped tube after maceration by Deng et al. (2007). The tubes were tightly closed and the contents were vigorously shaken and allowed to stand over night at room 
temperature. Moreover, the tubes were heated for 4 hours in water bath starting from $60^{\circ} \mathrm{C}$ till reach $110^{\circ} \mathrm{C}$ ensure complete digestion of the samples. The digestion tubes were vigorously shaken at 30 minutes' intervals during the heating period. The tubes were then left to cool at room temperature and diluted with $1 \mathrm{ml}$ deionized water (30\%) as well as reheated in water bath at $70 \mathrm{oC}$ to ensure complete digestion of the samples. At this point, all organic matrixes have been destroyed. Each tube was diluted with deionized water till reach $25 \mathrm{ml}$ and the digest was filtered with Whattman filter paper No. 42. The filtrates were collected in Pyrex glass test tubes capped with polyethylene film and kept at room temperature until analyzed for their cadmium and lead concentrations.

\subsubsection{Preparation of blank and standard solutions:}

Instrumental procedures for various analyses were based on those suggested in the operator manual of the Atomic Absorption Spectrophotometer. However, blank and standard solutions were prepared in the same manner as applied for wet digestion and by using the same chemicals (Shibamoto and Bjeldanes, 2000).

\subsection{Analysis:}

The digest, blanks and standard solutions were aspirated by Flame Atomic Absorption Spectrophotometer (VARIAN, Australia, model AA240 FS) and analyzed for heavy metals concentration. Absorbency of lead and cadmium were directly recorded from the digital scale. These concentration was calculated according to the following equation: $C=R \quad x \quad(D / W)$, where $\mathrm{C}=$ Concentration of heavy metal (wet weight), $\mathrm{R}=$ Reading of digital scale $\mathrm{D}=$ Dilution of the prepared sample. $\mathrm{W}=$ Weight of the sample.

\section{RESULTS}

The obtained results in table (1) revealed that the mean value of cadmium in the country (A) samples were $0.23 \pm 0.02,0.18 \pm 0.01$ and $0.11 \pm$ $0.01 \mathrm{ppm}$ in the Mackerel, Herring and Saurus, respectively. The average concentration of cadmium in country (B) samples were $0.19 \pm 0.01$, $0.13 \pm 0.01$ and $0.09 \pm 0.01 \mathrm{ppm}$ in the Mackerel, Herring and Saurus, respectively. Furthermore, in country (A), the percentage of unaccepted samples in table (2) were $26.67,26.67$ and $13.33 \%$ while the percentage of accepted samples were 73.33, 73.33 and $86.67 \%$ in the Mackerel, Herring and Saurus samples, respectively. In country (B), the percentage of unaccepted samples were 20.00, 13.33 and $13.33 \%$ while the percentage of accepted samples were $80,86.67$ and $86.67 \%$ in the Mackerel, Herring and Saurus samples, respectively.

Furthermore, the average concentration of lead in the country (A) samples in table (3) were $0.40 \pm 0.03,0.31 \pm 0.02$ and $0.19 \pm 0.01 \mathrm{ppm}$ in the Mackerel, Herring and Saurus, respectively. The average concentration of lead in country (B) samples were $0.27 \pm 0.02,0.20 \pm 0.01$ and $0.14 \pm$ $0.01 \mathrm{ppm}$ in the Mackerel, Herring and Saurus, respectively. In addition, in country (A), the percentage of unaccepted samples in table (4) were $46.67,33.33$ and $26.67 \%$ while the percentage of accepted samples were 53.33, 66.67 and $73.33 \%$ in the Mackerel, Herring and Saurus, respectively. In country (B), the percentage of unaccepted samples in table (4) were 40.00, 26.67 and $20 \%$ while the percentage of accepted samples were 60 , 73.33 and $80 \%$ in the Mackerel, Herring and Saurus, respectively.

Table (1): Statistical analytical results of cadmium levels (ppm) in the examined samples of in Imported Frozen Fish. $(n=15)$

\begin{tabular}{|c|c|c|c|}
\hline \multirow[b]{2}{*}{$\begin{array}{l}\text { country } \\
\text { fish }\end{array}$} & \multicolumn{2}{|c|}{ Max permissible } & \multirow[b]{2}{*}{$\begin{array}{l}\text { Mean } \\
\text { SEM* }\end{array}$} \\
\hline & $\begin{array}{l}\text { / limit } \\
\text { (mg \%)* }\end{array}$ & Min. Max. & \\
\hline \multicolumn{4}{|c|}{ country (A): } \\
\hline Mackerel & 0.05 & $0.03 \quad 0.44$ & $0.23 \pm 0.02$ \\
\hline Herring & 0.05 & $0.03 \quad 0.35$ & $0.18 \pm 0.01$ \\
\hline saurus & 0.05 & $0.01 \quad 0.23$ & $0.11 \pm 0.01$ \\
\hline \multicolumn{4}{|c|}{ country (B): } \\
\hline Mackerel & 0.05 & 0.020 .34 & $0.19 \pm 0.01$ \\
\hline Herring & 0.05 & 0.010 .26 & $0.13 \pm 0.01$ \\
\hline saurus & 0.05 & 0.010 .17 & $0.09+0.01$ \\
\hline
\end{tabular}

Table (2): Acceptability of the examined samples of fish based on their levels of cadmium $(n=15)$.

\begin{tabular}{|c|c|c|c|c|c|c|}
\hline \multirow{2}{*}{$\begin{array}{l}\text { country } \\
\text { fish }\end{array}$} & \multicolumn{2}{|c|}{$\begin{array}{l}\text { Positive } \\
\text { samples }\end{array}$} & \multicolumn{2}{|c|}{$\begin{array}{l}\text { accepted } \\
\text { Samples }\end{array}$} & \multicolumn{2}{|c|}{$\begin{array}{c}\text { Unaccepted } \\
\text { Samples }\end{array}$} \\
\hline & & No. $\%$ & No. & $\%$ & No. & $\%$ \\
\hline
\end{tabular}

\begin{tabular}{lcccccc}
\hline Country & & & & & & \\
A: & 8 & 53.33 & 11 & 73.33 & 4 & 26.67 \\
Mackerel & & & & & & \\
Herring & 6 & 40 & 11 & 73.33 & 4 & 26.67 \\
Saurus & 5 & 33.33 & 13 & 86.67 & 2 & 13.33 \\
Country & & & & & & \\
B: & 6 & 40 & 12 & 80 & 3 & 20 \\
Mackerel & & & & & & \\
Herring & 4 & 26.67 & 13 & 86.67 & 2 & 13.33 \\
Saurus & 3 & 20 & 13 & 86.67 & 2 & 13.33 \\
\hline
\end{tabular}


Table (3): Statistical analytical results of lead levels (ppm) in Imported Frozen Fish. $(\mathrm{n}=15)$

\begin{tabular}{|c|c|c|c|c|c|}
\hline $\begin{array}{l}\text { country } \\
\text { fish }\end{array}$ & $\begin{array}{r}\text { Ma } \\
\text { permis } \\
\text { lim } \\
(\mathrm{mg} \%)^{*}\end{array}$ & ible & Min. & Max. & $\begin{array}{c}\text { Mean } \pm \\
\text { S.E* }\end{array}$ \\
\hline \multicolumn{6}{|l|}{ country $(A)$ : } \\
\hline Mackerel & 0.10 & 0.06 & 0.83 & & $40 \pm 0.03$ \\
\hline Herring & 0.10 & 0.05 & 0.68 & & $31 \pm 0.02$ \\
\hline saurus & 0.10 & 0.02 & 0.37 & & $19 \pm 0.01$ \\
\hline country (B): & 0.10 & & & & \\
\hline Mackerel & & 0.05 & 0.61 & & $27 \pm 0.02$ \\
\hline Herring & 0.10 & 0.03 & 0.49 & & $20 \pm 0.01$ \\
\hline saurus & 0.10 & 0.01 & 0.28 & & $14 \pm 0.01$ \\
\hline
\end{tabular}

Table (4): Acceptability of the examined samples of Imported Frozen Fish. Based on their levels of lead. $(n=15)$

\begin{tabular}{llll}
\hline \multirow{2}{*}{$\begin{array}{l}\text { country } \\
\text { fish }\end{array}$} & Positive & accepted & Unaccepted \\
& samples & Samples & Samples \\
& No. $\%$ & No. $\%$ & No. $\%$ \\
\hline
\end{tabular}

\begin{tabular}{lllllll}
\hline Country & & & & & & \\
A: & 10 & 66.67 & 8 & 53.33 & 7 & 46.67 \\
Mackerel & & & & & \\
Herring & 10 & 66.67 & 10 & 66.67 & 5 & 33.33 \\
$\begin{array}{l}\text { Saurus } \\
\text { Country }\end{array}$ & 8 & 53.33 & 11 & 73.33 & 4 & 26.67 \\
B: & 9 & 60 & 9 & 60 & 6 & 40 \\
Mackerel & & & & & & \\
Herring & 7 & 46.67 & 11 & 73.33 & 4 & 26.67 \\
Saurus & 6 & 40 & 12 & 80 & 3 & 20 \\
\hline
\end{tabular}

\section{DISCUSSION}

From the obtained results, the collected imported frozen fish samples (Mackerel, Herring and Saurus) were highly contaminated with toxic heavy metals residues (cadmium and lead). Regarding the products contamination, the highest cadmium contamination was in Mackerel followed by Herring then Saurus. The current results in cadmium relatively agree with those recorded by Reham (2011) surveyed that the cadmium concentration in examined samples of frozen pangasius hypophthalmus fish and frozen sardine ranged from 0.03 to 0.24 and 0.04 to 0.42 with a mean value of $0.11 \pm 0.01$ and $0.14 \pm 0.02 \mathrm{mg} / \mathrm{kg}$ wet weight, respectively. El-Sayed (2010) cited that the average concentration of cadmium in fresh water fish, canned fish, pickled fish, smoked fish samples were $0.09 \pm 0.01,0.11 \pm 0.01,0.14 \pm$ $0.01,0.18 \pm 0.02 \mathrm{mg} / \mathrm{kg}$, respectively. Şireli et al.
(2006) recorded that the cadmium concentration ranged from 0.003 to 0.036 with a mean value of $0.01367 \mathrm{mg} / \mathrm{kg}$ wet weight, in the examined samples of smoked fish. In human, $\mathrm{Cd}$ is highly cumulative poison with a biological half-life about 20-30 years in human body (Manahan, 1992). Our findings revealed that, Mackerel showed the highest lead contamination followed by Herring then Saurus. The obtained results agree with those recorded by Reham (2011) observed that the lead concentration in examined samples of frozen pangasiushy pophthalmus fish and frozen sardine ranged from 0.05 to 0.31 and 0.02 to 0.18 with a mean value of $0.15 \pm 0.01$ and $0.09 \pm 0.01 \mathrm{mg} / \mathrm{kg}$ wet weight, respectively. El-Sayed (2010) cited that the average concentration of lead in fresh water fish, canned fish, pickled fish and smoked fish samples were $0.06 \pm 0.01,0.15 \pm 0.01,0.18 \pm$ $0.02,0.32 \pm 0.02 \mathrm{mg} / \mathrm{kg}$, respectively. Also the obtained results agree with El-Dahbi-Dina (2006); Mohamed (2009) and El-Mowafi (1995). In contrast, these results disagree with those observed by Noha and Ghada (2007), Şireli et al. (2006) Virbickas and Sakalausklene (2006), Celik et al. (2004) and Abd El-Nasser et al. (1996). Lead poisoning may cause leg cramps, muscular weakness, central nervous system depression and coma (Mason, 1991). Also, lead considered as one of toxic substance which accumulates in the body due to its low rate of elimination. The classic symptoms of lead poisoning are colic, anemia and encephalopathy (Chisolm, 1973).

It could be inferred that regarding the product contamination, the highest cadmium and lead contamination was in Mackerel followed by Herring then Saurus.

\section{REFERENCES}

Abd El-Nasser, M., Shaaban, A.A., Sayed, M.M., 1996. Level of some heavy metals in fish caught from river Nile at Assiut Governorate, Egypt. Assiut Vet. Med. J. 34, 68.

Andreji, J., Stranai, Z., Massonyl, P., Valent, M., 2005. Concentration of selected metal in muscle of various fish species. J. Environ. Sci. Heal. 40, 899-912.

Celik, U., Cakli, S., Oehlenschlager, J., 2004. Determination of the lead and cadmium burden in some North Eastern Atlantic and Mediterranean fish species by DPSAV. European Food Res. and Technol. 218, 298.

Chisolm, J., 1973. Management of increased lead absorbtion and lead poisoning in children. N. Engl. J. Med. 289, 1016-1017. 
Codex Alimentarius Commission Procedural Manual, 2001. Twelfth Edition. 9, 149-158.

Deng, H., Zhang, C., Chang, Z., Wang, Y., 2007. Trace metal concentration in Greet Tit (Parus major) and Greenfinch (Carduelissinica) at the Western Mountains of Beijing, China. Environmental Pollution 148, 620-626.

El-Dahbi-Dina, I.M. 2006. Microbiological and chemical studies on some fish and fish products in Menoufia GovernorateM.V.Sc, Menoufia Univ.

El-Mowafi, A.F.A. 1995. Role of some mineral in fish nutritionPhD, Zagazig University.

El-Sayed, E.A. 2010. Stuides on some chemical residue in fish and its products $\mathrm{PhD}$, Benha university.

FAO/WHO, 1992. Codex alimentarius commission, standard programme codex committee. On food additives and contaminants 24th session hague, 23-28 March.

Manahan, S.E., 1992. Toxicological chemistry, $2^{\text {nd }}$ ed. Lewis publishers Inc. Boca Raon, Ann. Arbor, London, Tokyo.

Mason, C.F., 1991. Biology of fresh water pollution, $2^{\text {nd }}$ ed. John wiley and Sons Inc., New York.
Mohamed, I.A. 2009. Toxic residues in some fresh water fishesM.V.Sc., Benha Univ. Egypt.

Noha, R.M.A., Ghada, S.E.S., 2007. Heavy metals residue in some fresh Egyptian fishes. Vet. Med. J. Giza 55, 787-798.

Reham, A.A., 2011. Heavy metal residues in imported frozen fish and Pangasius hypophthalmus (BASA) fish fillets BVMJ 2, 13-21.

Shibamoto, T., Bjeldanes, L.F., 2000. Heavy contents in some meat products. Toxilo. Envir. Chem. 42, 113-117.

Şireli, U.T., Göncüoğlu , M., Yıldırım, Y., Göncüoğlu, A., Çakmak, O., 2006. Assessment of Heavy Metals (Cadmium and Lead) in Vacuum Packaged Smoked Fish Species. Journal of Fisheries \& Aquatic Sciences 23, 353-356.

Underwood, E.J., 1977. Trace elements in Human and animalnutrition.4th Ed. Academic Press New York, Sanfranscico, London A subsidiary of Harcaurt Brace J ovanorich, Publisher. contents in some meat products. Toxilo. Envir. Chem. 42, 113-117.

Virbickas, T., Sakalausklene, G., 2006. Heavy metals in fish muscle in the Rivers of Lithuania. Acta-Zoologica-Lituanica 16, 271-278. 